ARTICLES

\title{
Using Facebook to Locate Sample Members
}

Bryan Rhodes ${ }^{1}$, Ellen Marks

${ }^{1}$ RTI

Keywords: survey practice

https://doi.org/10.29115/SP-2011-0023

Survey Practice

Vol. 4, Issue 5, 2011

Using Facebook to Locate Sample Members

Locating and retaining sample members is a challenge for any longitudinal study. If sample members are lost to follow-up, the potential for non-response bias increases and power for analyses decreases. Survey researchers have several tools available to locate sample members and a new one has emerged: the internet. This article reports on the use of social media-in particular, Facebook-to contact participants in a longitudinal study and encourage them to complete a telephone interview. Individuals we located on Facebook were significantly more likely to be white, have attended at least some college, and have higher household incomes than the rest of the study sample.

We then identify two categories of completed interviews associated with Facebook: those achieved (1) as a direct result of our Facebook contact and (2) seemingly because they were influenced by the Facebook contact. There were no significant differences on several demographic measures for the former group, but the latter shows differences in race/ethnicity, education, age, and household income-and not always in expected directions. We conclude that Facebook can be an effective tool for locating and contacting sample members who have not replied to more traditional attempts to reach them.

The internet's presence in American life has become pervasive: nearly $70 \%$ of U.S. households have internet service (U.S. Census Bureau 2010), and more than $95 \%$ of U.S. adults accessed the internet in the past year (World Bank 2011). The widespread availability of the internet means that social networking sites-such as Facebook, MySpace, or LinkedIn - have become an integral part of many users' internet experience. The most commonly used one is Facebook with over 157 million visitors in May 2011 alone (Lipsman 2011), and more than 750 million active users (Facebook Statistics 2011). As social networking sites (SNS) have extended their reach into the population, survey researchers have attempted to leverage them, but little research on methods or results has been published. One longitudinal study reported a $4.6 \%$ reduction in attrition by using Facebook and MySpace to locate and contact sample members (Nwadiuko et al. 2010). Another study used Facebook and MySpace to locate sample members; of 406 messages sent to SNS, 29 (7.1\%) resulted in completed interviews (Perkins, Granger, and Saleska 2009). Both studies surveyed young adults, a group with particularly high rates of SNS usage (Wilkinson and 
Thelwall 2010). Both studies were conducted several years ago so would not have benefited from SNS expansion (since 2009 Facebook's user base has grown by $200 \%$ (Foster 2010)).

\section{Study Description}

SEED for Oklahoma Kids (SEED OK) is a random assignment experiment to test the impacts of giving every child a savings account at birth, "seeded" with an initial deposit and offering additional funds to match deposits. A random sample was drawn from birth records in Oklahoma, stratified by geographic location, with oversamples of American Indians, Hispanics, and African Americans. RTI conducted baseline telephone interviews with the sampled child's mother shortly after birth and a follow-up survey 3 years later.

The follow-up survey first attempted to contact sample members through mailings, e-mail, and telephone. When a sample member could not be reached, the case was assigned to field staff who attempted to locate sample members in person and encourage them to call in to complete the survey.

As field personnel were attempting in-person locating, two project staff used Facebook to attempt to locate and contact non-respondents. The locators used their own personal Facebook accounts; we considered setting up new accounts solely to locate and contact sample members but felt that messages from a new Facebook account with few or no friends might look like 'spam' to recipients.

Each locator had basic information about sample members including full name, best known address, age, e-mail address, and child's name. Locators used Facebook's built- in search feature to locate sample members.

Once the locator found a profile that appeared to be the sample member, she sent a message to the sample member. A Facebook message is not public and can be viewed only by the message's sender and recipient. The message said we were looking for someone with the sample member's name who participated in the SEED OK survey about three years ago, and asked that if we had the right person she call a toll-free number to complete the interview.

\section{Results}

Locators attempted to find 919 sample members on Facebook, all of whom had not been reached through previous telephone or mail attempts. This group was significantly more likely to be American Indian or Hispanic (compared to African American or Caucasian), have not attended college, be single, and be over 30 years old. ${ }^{1}$ 
Exhibit 1 Demographic composition of sample members located on Facebook.

$\begin{array}{lll}\text { Race/ethnicity** } & \\ \text { White (other) } & & 35.36 \\ \text { African American } & 47.96 & 16.80 \\ \text { American Indian } & 17.01 & 21.76 \\ \text { Hispanic } & 24.15 & 26.08 \\ \text { Education** } & 10.88 & \\ \text { Less than high school } & & 38.40 \\ \text { High school diploma or GED } & 25.85 & 34.88 \\ \text { Some college or more } & 34.69 & 26.72 \\ \text { Marital Status } & 39.46 & \\ \text { Married } & & 47.04 \\ \text { Divorced, separated, or widowed } & 50.34 & 10.08 \\ \text { Single (never married) } & 8.50 & 42.88 \\ \text { Age } & 41.16 & \\ \text { Less than 25 } & & 59.20 \\ 25 \text { to 30 } & 52.38 & 28.96 \\ 31 \text { or older } & 31.63 & 11.84 \\ \text { Household Income }{ }^{\text {b,** }} & 15.99 & \\ \text { Low } & & 52.38 \\ \text { Middle } & 39.74 & 32.99 \\ \text { High } & 38.49 & 14.63\end{array}$

a This group contains all other racial categories, but consists primarily of Caucasian sample members.

b The sample is split into three categories based on an income measurement that uses an equivalence scale to account for different household sizes. ${ }^{* *} \mathrm{p} \leq .01$

Of the 919 we tried to locate on Facebook, we found profiles and sent messages to 294 sample members $(32 \%) .{ }^{2}$ Our efforts were more successful in locating some demographic groups than others. As shown in Exhibit 1, study participants located through Facebook were significantly more likely to be white, have attended at least some college, and have higher household incomes. ${ }^{3}$

Since the study was attempting to locate and contact sample members by phone and in person concurrently with the Facebook locating effort, we cannot tease apart the unique effect of the Facebook message on survey completion rates. We can, however, credit the Facebook message as contributing to a completed interview if it was our last contact with the sample member before she completed the interview. Of 294 sample members, 92 (31\%) received a Facebook message and then completed an interview. Thus, sending a Facebook

\footnotetext{
2 Although staff felt that these Facebook pages matched the sample members, there is no way to be certain that the message was sent to the correct person (rather than someone with the same name) or that the recipient read the message.

3 All demographic characteristics are based on responses to the baseline survey.
} 
message eliminated the need for further in-person or telephone outreach by $10 \%$ (92 of 919 non-respondents). These Facebook completes represent $4 \%$ of all completed interviews.

We next examined Facebook completes by demographic characteristics (Exhibit 2). Although there were differences in characteristics for sample members located through Facebook, there are no statistically significant differences in characteristics for sample members who completed interviews.

Although we attribute only 92 completed interviews directly to the Facebook effort, there is some evidence that the Facebook communication helped sway sample members to respond to phone and in-person attempts to locate them. Of those contacted on Facebook, 215 of 294 (73 percent) ultimately completed an interview for the study - significantly more than those we attempted to locate on Facebook but could not, suggesting the Facebook message may have had some influence on the respondent's decision to complete the interview. Those who ultimately completed the interview after being contacted through Facebook were significantly different from the rest of the sample on race/ ethnicity, education, age, and income. Exhibit 2 shows comparisons between (1) completes directly attributed to Facebook and all other completed interviews and (2) completes influenced by Facebook contact (including those directly attributed) and all other completed interviews. As an example, the race/ethnicity of interviews completed as a direct result of contact with Facebook users (column 1) was not significantly different from the race/ ethnicity of all other completed interviews (column 2), but the race/ethnicity of those whose completion of the interview may have been influenced by the Facebook message (column 3) was significantly different from all others (column 4).

We then examined whether the Facebook completes differed from the rest of the sample on an important outcome variable: whether they had saved for their child's education. ${ }^{4}$ Those who ultimately completed the interview after being contacted through Facebook were not significantly more likely to have savings for their child's college education.

We also constructed logistic models that included all variables from the above analyses (Exhibits 1 and 2), but we quickly ran into problems with intercorrelation, small cell sizes (often less than 5 or 10 cases), and large standard errors. We believe multivariate analyses are important for understanding the relationships at play and hope that other studies will soon have enough cases to warrant this type of investigation. 
Exhibit 2 Comparison of Facebook completes to all other completed interviews.

\begin{tabular}{|c|c|c|c|c|c|}
\hline & $\begin{array}{l}\text { Direct Facebook } \\
\text { Completes }(n=92)\end{array}$ & $\begin{array}{l}\text { Other } \\
\text { completes } \\
(n=2,208)\end{array}$ & $\begin{array}{l}\text { Completes influenced } \\
\text { by Facebook }(n=215)\end{array}$ & $\begin{array}{l}\text { Other } \\
\text { completes } \\
(n=2,085)\end{array}$ & $\begin{array}{l}\text { All } \\
\text { completes } \\
(n=2,300)\end{array}$ \\
\hline Race/ethnicity & & & $*$ & & \\
\hline White (other) & 55.43 & 48.01 & 50.70 & 48.06 & 48.30 \\
\hline African American & 15.22 & 17.30 & 13.95 & 17.55 & 17.22 \\
\hline American Indian & 22.83 & 18.93 & 25.58 & 18.42 & 19.09 \\
\hline Hispanic & 6.52 & 15.76 & 9.77 & 15.97 & 15.39 \\
\hline Education & & & $*$ & & \\
\hline $\begin{array}{l}\text { Less than high } \\
\text { school }\end{array}$ & 21.74 & 22.15 & 23.26 & 22.01 & 22.13 \\
\hline $\begin{array}{l}\text { High school } \\
\text { diploma or GED }\end{array}$ & 32.61 & 28.35 & 35.81 & 27.77 & 28.52 \\
\hline $\begin{array}{l}\text { Some college or } \\
\text { more }\end{array}$ & 45.65 & 49.50 & 40.93 & 50.22 & 49.35 \\
\hline \multicolumn{6}{|l|}{ Marital Status } \\
\hline Married & 59.78 & 58.38 & 51.63 & 59.14 & 58.43 \\
\hline $\begin{array}{l}\text { Divorced, } \\
\text { separated, or } \\
\text { widowed }\end{array}$ & 7.61 & 7.20 & 6.98 & 7.24 & 7.22 \\
\hline $\begin{array}{l}\text { Single (never } \\
\text { married) }\end{array}$ & 32.61 & 34.42 & 41.40 & 33.62 & 34.35 \\
\hline Age & & & * & & \\
\hline Less than 25 & 53.26 & 42.39 & 53.95 & 41.68 & 42.83 \\
\hline 25 to 30 & 29.35 & 35.05 & 30.70 & 35.25 & 34.83 \\
\hline 31 or older & 17.39 & 22.55 & 15.35 & 23.07 & 22.35 \\
\hline Household Income & & & $*$ & & \\
\hline Low & 33.72 & 46.97 & 38.35 & 34.84 & 35.17 \\
\hline Middle & 37.21 & 23.86 & 40.29 & 33.50 & 34.13 \\
\hline High & 29.07 & 29.17 & 21.36 & 31.66 & 30.70 \\
\hline \multicolumn{6}{|c|}{ Have savings for child's college } \\
\hline Yes & 34.07 & 33.65 & 28.04 & 34.35 & 33.76 \\
\hline No & 65.93 & 66.35 & 71.96 & 65.65 & 66.24 \\
\hline
\end{tabular}

${ }^{*} \mathrm{p} \leq .05$.

\section{Conclusions}

Facebook can be an effective tool for locating and contacting sample members who have not replied to more traditional attempts to reach them. This kind of Facebook effort can increase overall response rates and can be particularly effective for certain demographic groups, namely younger and more highly educated sample members-essentially mirroring the population of Facebook users.

We had greater success locating and contacting sample members through SNS than previous studies, most likely because of increased use of SNS (particularly Facebook) since the previous studies were fielded. Importantly, Facebook was effective in locating sample members across a range of demographic characteristics. 
Sample members who were contacted through Facebook and subsequently completed the follow-up interview were significantly different from those contacted in some other way. This difference suggests that we were able to reach segments of the sample through Facebook that we might not have otherwise been able to contact, potentially reducing non-response bias. 


\section{REFERENCES}

Facebook Statistics. 2011. 2011. https://www.facebook.com/press/info.php?statistics.

Foster, B. 2010. “Facebook User Growth Chart - 2004-2011.” http://www.benphoster.com/ facebook-user-growth-chart-2004-2010.

Lipsman, A. 2011. “The Network Effect: Facebook, Linkedin, Twitter \& Tumblr Reach New Heights in May.” ComScore Voices (blog). June 15, 2011. http://blog.comscore.com/2011/06/ facebook \linkedin \twitter \tumblr.html.

Marks, E., B. Rhodes, and S. Scheffler. 2008. SEED for Oklaboma Kids: Baseline Analysis. Research Triangle Park, NC: RTI International.

Nwadiuko, Joseph, Patricia Isbell, Adam J. Zolotor, Jon Hussey, and Jonathan B. Kotch. 2010. "Using Social Networking Sites in Subject Tracing.” Field Methods 23 (1): 77-85. https://doi.org/ 10.1177/1525822x10384088.

Perkins, J.L., R.K. Granger, and E.L. Saleska. 2009. "Data Security Considerations When Using Social Networking Websites for Locating and Contacting Sample Members.” Presented at the IFD\&TC 2009, May.

U.S. Census Bureau. 2010. "Statistical Abstract of the United States: 2011 (130th Edition).” Washington, DC.

Wilkinson, David, and Mike Thelwall. 2010. "Social Network Site Changes over Time: The Case of MySpace." Journal of the American Society for Information Science and Technology 61 (11): 2311-23. https://doi.org/10.1002/asi.21397.

World Bank. 2011. “World Development Indicators.” 2011. http://data.worldbank.org/data-catalog/ world-development-indicators. 